\title{
What MAKES A "LEADING" CASE
}

\author{
Rt Hon Sir Ivor Richardson*
}

The theme developed in the paper is that what makes a leading case is not immediately apparent or able to be captured in a short definition. The crucial questions are how and why a case is seen to be or to have been particularly influential in settling an area of the law. Exploring these questions necessarily involves viewing the case in its historical context. Economic and behavioural implications and impacts should also be kept in mind.

The paper draws on empirical research involving retired judges, experienced lawyers and judges' clerks and on specialist essays by senior academic lawyers produced for the 50th anniversary conference of the Court of Appeal in 2008. The research results show how much room there is for differing assessments of significance. The second half of the paper discusses a range of appeal cases explaining how and why the Court focussed on particular matters of significance in deciding the cases

\section{INTRODUCTION}

I started thinking seriously about the question, what makes a leading case, when working on the history of the Court of Appeal for the 50th anniversary conference of the Court, included along with specific subject-area essays in The Permanent New Zealand Court of Appeal: Essays on the First 50 Years. ${ }^{1}$

The question, why is a particular case significant, is also important in the research project for Recovering New Zealand's Lost Cases which is focussing on Supreme Court decisions from18411883 and Native Land Court decisions from the first 20 years of that court.

* Distinguished Fellow, Law Faculty, Victoria University of Wellington. Judge of the New Zealand Court of Appeal 1977 to 2002, President 1996-2002.

1 Rick Bigwood (ed) The Permanent New Zealand Court of Appeal: Essays on the First 50 Years (Hart Publishing, Oxford, 2009). 


\section{FIVE BACKGROUND POINTS}

\section{A There is Value in Comparing Different Perspectives}

I start with five background points. First, cases do not arrive in the court system labelled "leading case". A case that may initially seem important may subsequently be regarded as of limited significance, except to the parties. What may initially escape notice may later be viewed as truly significant in illuminating the development of our laws and changes in New Zealand society. Answering the question, what are our leading cases, necessarily involves historical analysis, viewing the case, whenever decided, both in its historical context and its contemporary relevance.

It follows that the identification of what makes a leading case is not the exclusive preserve of judges and lawyers (practising and academic). They have the expertise to provide crucial perspectives. But, the public policy impacts of judicial decisions are also the legitimate concerns of legislators, administrators, political scientists, sociologists, historians, philosophers, economists, educators and the news media. Some studies have been concerned with resource and behavioural implications of the functioning of the courts. Others have contained detailed analyses (including comparisons across jurisdictions) of structures of judgments, reasoning methods and citation practices. Whatever their special fields, their different perspectives can helpfully be compared and contrasted with those of judges and lawyers.

And a wide view of what cases are significant is clearly important in the identification of "lost cases". The project team for Recovering New Zealand's Lost Cases emphasises the importance of assessing cases in their contemporary contexts, decade by decade. That involves searching through newspapers and other secondary sources to identify cases of potential importance and then classifying, processing and assessing their significance.

\section{B Research Projects have to be Linked to Particular Courts and Periods}

Second, to try to compile a list of all the leading cases decided by the New Zealand courts would be a mammoth undertaking. It would require a comprehensive database of all cases decided with reasoned decisions by all courts since 1840 and would have to cover hundreds of thousands of cases over a vast range of activities resolved through the adversarial processes. To be practical, any research project has to be linked to particular courts and periods.

In round terms 14,000 reasoned decisions were given following hearing by the Court of Appeal over the 50 years. For the same period the case numbers in the High Court were many times those of the Court of Appeal and, overwhelming those totals, the District Court and its predecessors have always disposed of the vast bulk of cases decided in the court system, as reflected in the workload figures analysed in the voluminous Report of the Royal Commission on the Courts. ${ }^{2}$

2 Report of the Royal Commission on the Courts [1978] AJHR H2. 
The breakdown between civil and criminal is important. While as late as 1990 the civil decisions of the Court of Appeal (188) were fairly close in numbers to criminal decisions (208), in 2000 and 2007 there were in round terms twice as many criminal decisions (301 as against 157 civil decisions in 2000 and 375 as against 197 in 2007). ${ }^{3}$ But there were sufficient civil decisions throughout the 50 years to require those contributing and focussing on significant cases to be selective.

\section{Formulating Lists of Significant Cases for History Essay}

Third, as part of the research for the history essay two small groups were asked to formulate their individual lists of significant cases decade by decade over the five decades: ${ }^{4}$ the nine judges' clerks at the Court in 2007 and, toward the other end of the time spectrum, 10 retired judges (nine former permanent members of the Court and Doogue J, a very experienced trial and Divisional Court judge) and two very experienced lawyers. The decade approach was to avoid any risk of overfocus on recent years. I should add that I did not prepare an individual list because I did not want to be subconsciously influenced in writing up that section of the history.

The brief to each of the nine clerks was to name from each decade no more than two or three cases they considered particularly significant for New Zealand and, for each case selected, to say why briefly (in no more than two sentences). The overlap figures were interesting. Only 10 of the 69 in the combined lists were included in more than four individual lists with 47 of the 69 being included once or twice in the separate lists and a further eight in only three lists.

The second group were given the combined lists of the clerks and invited to provide individual lists (not more than two or three in each decade, and without feeling the need to identify cases from each decade), and for each case to say why (again briefly). Only eight of the 71 in the combined lists were included in more than four individual lists with a further five of the 71 included in four individual lists.

Interestingly, only 29 cases were common to both lists and of the 10 included in more than four clerks' lists only five were present in more than four of the judges' and lawyers' lists. Widening the comparison base to four or more adds just three more cases. One clerk commented that her law school education drew her attention to relatively few early Court of Appeal cases and gave a much greater sense of recent cases, probably out of proportion in an historical context.

The full combined lists are at Appendix E: 4 of the history, ${ }^{5}$ which also shows the number of times each case appeared in more than one individual list. The diverse responses both within and between the two groups show that identifying leading cases is not straightforward. Accordingly, the

3 Sir Ivor Richardson "The Permanent Court of Appeal: Surveying the 50 Years" in Bigwood, above n 1, 297 at Appendix A [the "history essay"].

4 Ibid, at Appendix E.

5 Ibid, at 367-369. 
history chapter noted that the material provided warranted an extensive stand-alone research study to analyse and draw conclusions from all cases selected and the reasons for their selection. ${ }^{6}$

\section{Cases identified in subject-area essays}

Fourth and turning to the subject-area cases, that passage went on to note that such a study could also explore some striking differences between the two lists and the cases identified in the subjectarea analyses comprising the other chapters in the book. It was recognised that the one day 50th anniversary conference could not be expected to be comprehensive. In the event it was confined to eight specific subject-areas with their specialist contributors:

- Professor Jim Evans: who was asked to focus on "Precedent in New Zealand's Permanent Court of Appeal";

- Professor Philip Joseph: "The Contribution of the Court of Appeal to Commonwealth Administrative Law";

- Professor ATH Smith: "Fifty Years of Criminal Appeals in the Permanent Court of Appeal", which, for reasons he gave, excluded substantive criminal law;

- Professors Mark Henaghan and Nicola Peart: "Relationship Property Appeals in the New Zealand Court of Appeal 1958-2008: The Elusiveness of Equality";

- Professor Stephen Todd: "The Court of Appeal, Accident Compensation and Tort Litigation";

- $\quad$ Professor Peter Watts: "Company law and the Court of Appeal 1958-2008";

- Dr JK Maxton: "Equity in Commercial Dealings";

- Associate Professor RP Boast: "The Court of Appeal and Indigenous Rights: From NinetyMile Beach to Ngati Apa".

The specialist essays discussed around 150 Court of Appeal decisions and cited several hundred more. The combined total of "significant" cases identified in the two lists in the history essays ${ }^{7}$ and the some 150 discussed in the specialist essays (without any reduction for some of the overlapping in those sub-totals) is only a tiny fraction of the 14,000 reasoned decisions of the Court over the 50 years. A comprehensive study would have required an army of specialist commentators with different contributors on each topic providing different perspectives. Clearly, too, the particular focus of each of the specific subject-area papers inevitably meant that there were still large gaps in the coverage of the work of the Court.

For example, revenue law (involving appeals in taxes and duties with substantive law and process questions including major judicial review cases) of which there were some 120 reported decisions by the Court and over 30 in the Privy Council, had only some 10 case citations in the

6 Ibid, at 313.

7 Ibid, at 68 and 71. 
subject area chapters and in the two lists in the history chapter. Perhaps equally if not more striking was the absence of any focus on employment, regulating commerce, legislative interpretation particularly given the increasing prominence of New Zealand statute law and the corresponding decline of judge-made common law, ${ }^{8}$ constitutional law and human rights.

Again, and because that was not part of their focus, the clerks and the judges and lawyers lists did not bring out the uneasy relationship at times between the Court of Appeal jurisprudence and the values of the Privy Council judges in various economic, social and national identity areas, where the Privy Council "might", but at other times did not, emphasise the importance of local conditions. ${ }^{9}$ Interestingly, some of the specific subject-area essays did so, notably Professor Evans on Precedent, where he carefully traversed the slow and deliberate steps in which the Court grappled with the questions of when and applying what tests it would depart from its own decisions. ${ }^{10}$ Professor Evans explained how consensus eventually coalesced after more than a decade around a passage from one of the judgments in the early decision in Collector of Customs v Lawrence Publishing Co $L t d,{ }^{11}$ and went on to consider how that approach had been worked out in later cases. And some other subject-area essays debated the respective stances of the Court and the Privy Council in some decisions, for example Professor Watts, Dr Maxton and Professor Todd when discussing the handful of exemplary damages decisions. ${ }^{12}$

\section{E Lord Cooke's Assessment in the 1996 Hamlyn Lectures}

Fifth, the Hamlyn Lectures of 1996 provide another perspective of significant cases by a New Zealander steeped in the law. Lord Cooke's series titled Turning Points of the Common Law focussed on some themes in company law, crime, tort and public law and discussed relevant cases from various jurisdictions. ${ }^{13}$ Thirty of the 146 cases listed in the Table of Cases were from New Zealand but 10 were either outside the 1958-2007 period of the Court of Appeal conference or were High Court decisions. The lectures were not directed to either family law or precedent cases and the seven substantive criminal law cases and six tort cases discussed by Lord Cooke were not from areas covered in the subject-area chapters at the conference. However, and perhaps surprisingly, only 10 of the 20 cases from the period discussed by Lord Cooke were included in either (or both) of the Clerks and the Judges and Lawyers' lists.

8 Ibid, at 310

9 Ibid, at $319-325$

10 Jim Evans "Precedent in New Zealand Permanent Court of Appeal" in Bigwood, above n 1, at 1-40.

11 Collector of Customs v Lawrence Publishing Co Ltd [1986] 1 NZLR 404 at 414-415 (CA).

12 Stephen Todd "The Court of Appeal, Accident Compensation and tort litigation" in Bigwood above n 1 151, at 197-201.

13 Lord Cooke of Thorndon Turning Points of the Common Law (Sweet \& Maxwell, London, 1997). 


\section{WHAT MAKES A LEADING CASE: COMPARING SOME LEGAL SCHOLARLY WORKS}

Following on from that long lead in I turn now to discuss what makes a leading case. I started by searching Google for web references to "leading cases" plus "law". The answer was "about 230,000" with advice to narrow the search. So I tried "what is a leading case" plus "law". That yielded only three references, two to American encyclopaedias and the third to what I found was a light-hearted account at the retirement function for a Queensland Magistrate in 2008.

I found it more helpful to consult and compare some legal scholarly works in a Wellington library. I mention only three. First, Professor David M Walker in his The Oxford Companion to Law (1980) states: ${ }^{14}$

\footnotetext{
A judicial decision is always regarded as the chief precedent or judicial statement of principle on a particular point. Such cases are always referred to in relevant textbooks and later cases, and various collections of leading cases have been published, notably JW Smith's Leading Cases in various branches of the Law (1837 and many later editions) and FT White \& OD Tudor's Leading Cases in Equity (1849 and later editions), which collect the leading cases on particular points and show by annotations how the principles stated in the leading cases have been applied in later cases.
}

Next, Butterworths New Zealand Law Dictionary pithily defines the term: "A case which has had the most influence in settling an area of the law."15 It is "leading" because it becomes recognised as an authoritative statement of the governing principle.

Finally, the Editor's Preface in New Zealand Law Reports Leading Cases,${ }^{16}$ covering the period from 1840 to 1958, emphasises the role of the New Zealand Law Reports as a filtering and research tool and as making available to lawyers the leading precedents from the period (the compilation totalling around 100 cases).

In his Clarendon Press study, Leading Cases in the Common Law, Professor Brian Simpson points out that: ${ }^{17}$

... it is no more than common sense to appreciate that it is misguided, if other relevant materials exist, to rely upon law reports alone to tell us what happened in the case, how the dispute arose, what the persons involved conceived the dispute to be about, how it came to be litigated, how it came to be decided the way it was, much less what the consequences were to the people or to others indirectly affected by the decision.

14 David M Walker Oxford Companion to Law (Oxford University Press, Oxford, 1980).

15 Peter Spiller Butterworths New Zealand Law Dictionary (6th ed, LexisNexis, Wellington 2005) at 168.

16 Bernard Robertson (ed) New Zealand Law Reports Leading Cases (LexisNexis, Wellington, 2005).

17 AW Brian Simpson Leading Cases in the Common Law (Clarendon Press, Oxford, 1996) at 11. 
And, so, as he asks in the Preface with respect to the cases he studied: ${ }^{18}$

Was Shelley's Case (1581) really a product of the doctrines of property law, or was it perhaps a political decision? Is it possible to tell? How does an antique quarrel about the capture of wild ducks, Keeble $v$ Hickeringill (1707), retain an educational and doctrinal significance nearly three centuries later? Was the very absurdity of Jee v. Audley (1787) perhaps its guarantee of immortality? Whatever happened about accidents at work before Priestley v. Fowler (1837), and what induced the victim's father in that case to take the unprecedented step of suing his employer for damages in tort law? Why did the case of Raffles v Wichelhaus and Busch (1864) ever come to court, and why did a case which includes no judicial opinion whatsoever become a focus of academic interest, principally fuelled by ignorance? What light does a historical analysis of Tipping $v$ St Helen's Smelting Company (1865) throw upon economic theories as to how nuisance cases arising out of conflicting land uses ought to be decided? Was the decision in Rylands $v$ Fletcher (1868) really about Mr Rylands' unprepossessing and still defective reservoir? What has the case of $R v$. Keyn (1876) to tell us about the value and the possibility of the ideal of the rule of law? What is the relationship between quack medicine, Carlill $v$. Carbolic Smoke Ball Company (1893), and the dogmatics of contract law?

\section{LAW LIBRARIES AND THE INTERNET ARE RESEARCH LABORATORIES}

Law libraries and the Internet provide access to a constantly expanding base of decided cases along with associated texts and other commentaries. The libraries and the internet are the raw material for the argument and resolution of legal issues in reasoned decisions in usually adversarial proceedings. They are the research laboratories for scholars, judges, lawyers (practising and academic) and students, as well as the working base for those immediately involved in the argument and resolution of particular cases. The usability of the material obviously depends on how well the input is selected, collected, constantly updated, classified, digested and indexed.

All courts have associated libraries. Their libraries and those of law schools, law reform and public sector advisory bodies, law firms and legal chambers often have a substantial range of associated sociological, economic, political science and historical materials. As one international statesman remarked, harking back to his student days: ${ }^{19}$

What was remarkable about our law faculty? First of all, it provided a comprehensive and wide-ranging curriculum. ... The underlying premise was that mastering purely juridical subjects required a fundamental knowledge of modern socio-economic and political processes, and, therefore had to be part of a comprehensive curriculum which included all the social sciences.

18 Ibid, at vii.

19 M Gorbachev Memoirs (Doubleday, New York, 1996) at 53. 
Similar comments could be made about the integration of sociological, economic, political and historical material into the teaching at our law schools. And New Zealand law collections follow the same patterns with general series and specialist subject-area reports and commentaries from New Zealand and a range of overseas jurisdictions and international law materials available directly and through computer based research.

\section{LAWYERS KNOW THAT RESOLVING LEGAL ARGUMENTS REQUIRES CONSIDERATION OF HISTORICAL DEVELOPMENTS AND BEHAVIOURAL IMPLICATIONS}

At first impression it may seem strange to many historians, and perhaps to some attending this conference, that neither "history" nor "legal history" is a separate chapter in the multi-volume The Laws of New Zealand and neither is listed in the detailed index. But, as all lawyers know, consideration of historical developments is basic to any legal argument and its resolution, and so is awareness of economic and behavioural implications and impacts. Professor Richard Boast's recent paper, "New Zealand legal history and 'mainstream' New Zealand history: a non-meeting of minds", should help dispel some myths. ${ }^{20}$

It is, of course, very helpful in setting the stage to have the identification and discussion of particular cases in the subject-area essays even though the contributing specialists were not asked specifically to answer the more general question about what makes a leading case. As earlier noted, the results of their combined endeavours yielded significantly different lists from those contained in the lists in the history essay. That may point to the desirability of bringing together a set of criteria against which to assess whether or not a decision can be considered a leading case. Even so, the cases listed in the history essay and the comments of those contributors bring out the real room for differing judgments at the end of the day.

As the history essay also noted, ${ }^{21}$ it may be worthwhile to reclassify cases identified in analyses overall and by decade by broad subject-area, for example, contract and commercial law, tort, equity, crime, public law - and, I suggest, to divide each into its sub-areas, and in that way build up a more extensive template.

\section{A Insights from those Contributing to the History Essay and Reflections on Some Cases they Listed}

One former judge commented that the number of times a case is subsequently cited does not measure its comparative importance. Some subjects may attract more litigation and social, economic

20 Richard Boast "New Zealand Legal History and 'Mainstream' New Zealand History: a Non-meeting of Minds" (paper presented to The Antipodes: New Directions in History and Culture Aotearoa New Zealand conference, Wellington, September 2009) (Publication forthcoming.).

21 Richardson, above $\mathrm{n} 3$, at 313. 
and political factors change over time and may affect the balance. The judge also observed that a case might be a "one off"' but nevertheless be of great constitutional or other importance. Another judge noted that his choices were influenced by how important a decision was in the day-to-day work of the courts, whether a decision was part of the development of a distinctively New Zealand jurisprudence, whether a decision had stood the test of time unscathed, or whether for some other reason a decision seemed of particular significance.

Taking a somewhat different perspective, another judge, in assessing significance, had regard to institutional and process issues as well as to substantive ones and also mentioned particular new statutes for each decade along with the cases as helping to provide some context. Again, the increasing impact in our legislation of New Zealand's international treaty obligations (and particularly the ascendancy of human rights laws often generally expressed and employing loosely textured language) and international conventions governing flows of goods, services and funds (including allocation of taxes) in an increasingly global world also affect decision making.

Where difficult problems arise there may well be differing views as to whether the Court should respond to a new situation as a common law development or leave it to the legislature to deal with it. For example, the Court divided in $R v$ Hughes over the contention that an undercover police officer need not disclose his identity to the defence. ${ }^{22}$ The majority concluded that under traditional common law principles the witness must give his true name and occupation if asked by the defence. The minority took the view that the request could be refused by a trial judge and listed series of principles to govern the exercise of the judge's discretion. Parliament promptly legislated to allow undercover officers to give evidence. But, as noted in the next Court of Appeal decision of $R v$ Hines (where the witness seeking anonymity was not an undercover officer but feared intimidation if obliged to disclose his true identity), when Parliament legislated in the wake of Hughes it adopted a much narrower approach than suggested by the minority judges in Hughes. ${ }^{23}$

The judgment in Hines had earlier discussed at some length major practical problems for the Courts in deciding public policy litigation, noting that court processes do not allow public policy to be developed in the systematic way that is regarded as desirable elsewhere in government. ${ }^{24}$ The passage contrasted the limited processes by which courts can obtain relevant information and then assess it, with the manner in which the Law Commission works by engaging in extensive research and analysis including gathering relevant facts, publishing discussion papers, evaluating responses, and then presenting final reports with draft Bills attached - which are then further subjected, as appropriate, to the general governmental and parliamentary legislative policy processes. In that regard, reflect, too, on Senator Fulbright's conclusion "You can't change society too much through

$22 R v$ Hughes [1996] 2 NZLR 129 (CA)

$23 \quad R v$ Hines [1997] 3 NZLR 529 at 543 (CA)

24 Ibid at 539-54 
the courts. Most of it has to come through the political system. Even if it takes longer, it's more likely to stick." 25

The history essay noted that a citation study could be helpful in assessing the relative significance of cases in their historical setting. ${ }^{26}$ Various considerations were noted including the significant reduction in the citation of older cases (from 43 per cent in 1960 less than 10 years' old to around 70 per cent by 1970 and on to 2007). Presumably, the essay observed, that reflects the influence of a host of factors, such as the rate of social change, increasing changes to the statute base and the increasing dominance generally of statute law and correspondingly lesser influence of the common law - and perhaps because older cases have not been entered into electronic databases relied on so much for legal research. ${ }^{27}$

I noted earlier the comment of one of the clerks that her law school education drew her attention to relatively few early Court of Appeal cases and suggested in the history essay that it could be worthwhile exploring whether there is any correlation between the selection of cases and the law schools attended by the clerks, the subjects taken and their teachers there. Another question, occasionally posed, is whether judicial attitudes are significantly affected by influential early teachers.

Overall, too, the judges and lawyers selected more cases from the middle decades and, though given the clerks' lists as a lead in, they clearly made their individual assessments, as the low overlap between the two lists demonstrates.

Comments in the history essay about three of the most ranked cases are also relevant to how those involved saw those cases. ${ }^{28}$ New Zealand Maori Council v Attorney General ${ }^{29}$ was overall the highest ranked case in the two lists. The decision was and continues to be of great significance, even though the legal answer required the orthodox application of well-settled principles governing judicial review of the exercise of statutory powers of decision by ministers and of the interpretation of the state-owned enterprises legislation in its statutory background. What the Court had to do was to provide both a factual base, including indicating some of the complexities surrounding the Treaty of Waitangi, sufficient to explain the legal answer, and give some guidance for those concerned with the tide of cases that were expected to follow (and did so) under the legislation.

25 Quoted in Bill Clinton My Life (Knopf, New York, 2004) at 127.

26 Richardson, above n 3, at 314.

27 Ibid, at 311.

28 Ibid, at 316.

29 New Zealand Maori Council v Attorney General [1987] 1 NZLR 641 (CA). 
Invercargill City Council v Hamlin determined major legal issues of great practical significance concerning the liability of local authorities to home owners for the carelessness of their building inspectors. ${ }^{30}$ Several clerks saw added significance in the emphasis given to developing New Zealand law to meet local conditions and in the hands-off response by the Privy Council on the further appeal.

Hosking $v$ Runting was a major privacy case concerning photographing families of celebrities out in the street. ${ }^{31}$ The comment in the text was that the different perceptions of the case by the clerks (in eight out of nine lists) and the judges and lawyers (only two out of 12) may suggest that for some in the latter group the amorphousness of the principle of the case meant it was too early to tell how significant it will be.

Finally, one Judge, thinking as he said more on broader lines of trends or developments, saw the most important development in the first decade as the beginning of the establishment of a New Zealand legal identity. In the second, he gave primacy to the development of matrimonial law, in the third to the two streams of administrative law and Waitangi issues, and in the fourth to the Bill of Rights cases, with no special trend discerned in the last decade, 1998 to 2007.

\section{B A Broad View of Significant Cases}

A few moments ago I noted that the legal answer in New Zealand Maori Council v Attorney General required the orthodox application of well-settled legal principles. The Judges from that case who spoke at the well-attended and lively symposium marking the 20th anniversary of the case emphasised that point. ${ }^{32}$ After a flood of comments questioning that view, one of the Judges said: "Well, all I can say is - read the judgments." I suggest that that interchange shows how the legal issues themselves had become invested with a much wider significance, essentially because of the impact of the case on Maori-Government relations and ultimately on the political history of New Zealand.

Keeping in mind Professor Simpson's questioning approach to the cases he studied, ${ }^{33}$ I will discuss a number of cases in my own experience and suggest various strands of significance in the reasoning of the judges. The particular focus of the first case is on language - determining the meaning of words in their context; the second is on administrative functioning - settling limits to the exercise of governmental power and facilitating effective administration; the third is on economic implications of decision-making; the fourth is on statutory interpretation - reflecting the historical

30 Invercargill City Council v Hamlin [1994] 3 NZLR 513 (CA).

31 Hosking $v$ Runting [2005] 1 NZLR 1 (CA).

32 Jacinta Ruru (ed) In Good Faith: Symposium Proceedings Marking the 20th Anniversary of the Lands Case (New Zealand Law Foundation, Wellington, 2008).

33 Simpson, above n 17, at 6-7. 
development of the statutory subject matter and the policies underlying related categories; the fifth is on the development of the common law of New Zealand - reflecting local conditions; and the sixth is on the duty of care in negligence - where the Court rejected claims against the Securities Commission and two newspapers in respect of failed investments in a finance company made as a result of reading its newspaper advertisements.

\section{King-Ansell v Police}

King-Ansell v Police was an extraordinary case. ${ }^{34}$ The appellant had been convicted under the Race Relations Act 1971 of publishing a pamphlet with intent to incite ill-will against a group of persons "on the ground of their ethnic origins." The major issue was whether Jewish people in New Zealand formed a group with common ethnic origins. The Court of Appeal was unanimous that they did. The meaning to be given to particular words in their different contexts is basic to all statutory interpretation. In any living language usages may change. An historical meaning may cease to be in current use. New usages may develop.

I suggest that the judgments in the case were significant for three reasons. The first was that the arguments advanced by counsel led to extended discussions of a range of English, American and New Zealand dictionaries. In that regard counsel for the appellant had contended that "ethnic" was to be confined to its ancient meaning applying to Gentiles, thus excluding Jews and Christians, and that certain later expanded meanings were to be disregarded as an American aberration. For my part I considered it helpful to cover in some detail, and by reference to the Oxford English Dictionary and its Supplements, the careful processes for recording actual usages that were followed in compiling dictionaries and attributing particular meanings to words as used in their different contexts.

The second was that the Race Relations Act 1971 explicitly implemented the International Convention on the Elimination of All Forms of Racial Discrimination. ${ }^{35}$ In my judgment I also concluded that an expression in English in an international Convention must have been intended by the framers to have essentially the same meaning in all English speaking countries implementing the English language text of the Convention and that our Acts Interpretation Act provisions allowed regard to be had to the international English usage of those expressions in the Convention. ${ }^{36}$

The third was that a sociologist with qualifications also in anthropology gave evidence concerning the modern connotations of the word "ethnic". There we felt that his conclusions had to be modified to accord with the Race Relations Act approach.

34 King-Ansell v Police [1979] 2 NZLR 531 (CA).

35 International Convention on the Elimination of All Forms of Racial Discrimination (opened for signature 21 December 1965, entered into force 4 January 1969).

36 King-Ansell v Police, above n 33, at 540-541. 
My ultimate conclusion was that: ${ }^{37}$

... a group is identifiable in terms of its ethnic origins if it is a segment of the population distinguished from others by a sufficient combination of shared customs, beliefs, traditions and characteristics derived from a common or presumed common past, even if not drawn from what in biological terms is a common racial stock. It is that combination which gives them an historically determined social identity in their own eyes and in the eyes of those outside the group. They have a distinct social identity based not simply on group cohesion and solidarity but also on their belief as to their historical antecedents.

\section{Van Gorkom v Attorney-General}

Van Gorkom v Attorney-General concerned the entitlement of a married woman teacher to removal expenses when transferring on promotion from one teaching position to another. ${ }^{38}$

Mrs Van Gorkom transferred from New Plymouth to Wellington. Her husband was in full-time employment outside the teaching profession.

A teacher's entitlement to removal expenses was governed by general conditions made by the Minister of Education under the Education (Salaries and Staffing) Regulations 1957. The removal expenses regime treated men and women differently. A married man living with his wife was entitled to all the expenses listed for moving the household. Paragraph C28.3.3 applied to a married woman teacher living with her husband who was not fully dependent on her. In that case she received personal expenses. Then, paragraph C28.3.4 provided that, where the married woman teacher was supporting a husband who was an invalid and dependent on her financially, payment of removal expenses as for a married man would be considered.

Regulation 16(2) applied only where the teacher was transferred on promotion. It was in the teacher's interests and in the wider interests of the education service, based as it was on progression through a career structure, that the teacher should do so. And so, whether the teacher was male or female, actual and reasonable expenses of removal to take up that position were to be borne by the Crown. The Court concluded that the Minister acted unreasonably in the administrative law sense and departed from the scheme of the regulations in approving paragraphs C28.3.3 and 28.3.4. On that answer counsel for both parties were agreed that the detailed provisions of the general conditions were to be applied to married women teachers as they were to men.

37 King-Ansell, above n 33. See also Mandla (Sewa Singh) v Dowell Lee [1983] 2 AC 548; $R(E) v$ Governing Body of JFS (United Synagogue intervening) [2009] UKSC 15, [2010] 2 WLR 153 at [185]-[186] per Lord Hope DP; Reid Mortensen, "Rendering to God and Caesar: Religion in Australian Discrimination Law" (1994-1995) 18 UQLJ 208 at 216-217; and Loretta de Plevitz and Larry Croft, "Aboriginality under the Microscope: The Biological Descent Test in Australian Law" (2003) 3 QUTLJJ 104 at 117-120.

38 Van Gorkom v Attorney-General [1978] 2 NZLR 387 (CA). 
That agreement avoided the need for an inquiry as to whether, in fact, the family of the teacher moved because of the teacher's appointment. We were conscious of the advantage of avoiding a factual inquiry in every case and went on to say: 39

We have no doubt that, in laying down general conditions pursuant to subcl (9), the Minister would be entitled to conclude that, in most cases where both spouses are employed, the wife's employment is considered by both spouses to be subordinate to the husband's career. It hardly needs to be said, too, that the Minister is entitled to consider it appropriate for reasons of administrative convenience to establish a rule that would cover the generality of cases so long as he does not purport to take away any rights conferred by the regulations...

It does not follow that the Minister is not entitled to differentiate in that respect between married male teachers and married female teachers. It would not be unreasonable for him to say that in today's society many women transferring in their employment, even on promotion, do so, at least primarily, because of and in the wake of the husband's career move. In many cases the expenses of shifting the household may fairly be characterised as expenses of his move rather than of her removal to take up her new post. In other cases the proper inference may be that the family would not have shifted unless both teacher wife and non-teacher husband wished to change their employments and that, as between themselves, it would be reasonable for each to contribute a proportion of the total costs of the family's move.

Needless to say, social changes over the last 30 years would bar that administrative approach!

\section{DHL International (NZ) Ltd v Richmond Ltd}

DHL International (NZ) Ltd v Richmond Ltd turned on its economic implications. ${ }^{40}$ Richmond engaged DHL to convey a package to Italy without disclosing that it contained a bearer bill of lading. Richmond indicated on the package containing the bill of lading that the package's contents had no commercial value and they did not obtain insurance. The bill of lading enabled the thief who stole it to obtain valuable goods in Italy. The holder of the bill went bankrupt, and the goods were not recoverable. Richmond sued DHL for the value of the goods. The standard form of contract contained a clause that excluded all liability "in any event" for consequential or special damages or other indirect loss "however arising" and imposed strict time limits on claims against DHL. The High Court, as many courts had tended to do, refused to give effect to the exclusion clause. The standard approach had been to treat such clauses with suspicion on account of assumed inequality of bargaining power and imperfect information.

We reversed the High Court's decision. As the exclusion was clearly worded, we felt that there was no justification for refusing to give it effect. Commercial parties know that the protection the contract provides is factored into the price - you get what you pay for. Commercial parties should

39 Ibid, at 392-393.

40 DHL International (NZ) Ltd v Richmond Ltd [1993] 3 NZLR 10 (CA). 
be aware of business risks and know that they can obtain insurance to protect against them. If they enter into a low-priced courier contract ( $\$ 22.50$ in the DHL case) that excludes liability on the part of the courier, then they are electing to bear any resulting losses. In return, they will have paid a lower price. The exclusion of liability will thus have been beneficial to both parties at the time of the contract. If, after entry into the contract and after losses have been suffered, courts refuse to enforce exclusion clauses, then they will be inhibiting mutually beneficial bargains. No one will be able to enter into a contract and negotiate a lower price relying in return on an exclusion of liability for consequential damages.

That reasoning may not apply in consumer cases. Consumers may not be expected to understand the effect of an exclusion clause. But DHL was not such a case. And consumers, and society and the courts, need not always view standard term contracts with deep suspicion. Such contracts may provide huge savings in transaction costs. No one taking a bus would expect to spend the first few minutes haggling over the fare. "Take it or leave it" promotes costs savings. Courts need to be alive to the economic implications of their, usually retrospective, rulings.

\section{Hadlee v Commissioner of Inland Revenue}

Hadlee $v$ Commissioner of Inland Revenue ${ }^{41}$ raised various arguments in relation to the taxing of professional partnership income. The only one I want to discuss today is whether, like employees, those self-employed are to be taxed on income earned from their personal exertion.

The taxpayer partner in a chartered accountancy firm had entered into legal arrangements designed to pass over to his family trust a share in his interests in the partnership and so in the profits of the partnership. The inquiry involved consideration of the historical development of the legislation and the scheme of various features. For much of its history the tax legislation had drawn a clear distinction between "earned" and "unearned" income. That distinction was important when differential rates applied to different categories and in the grant of some exemptions. In broad terms the distinction was between income from personal exertion and income from property. In relation to employment income the whole PAYE structure proceeded on the premise that income of that kind was derived by the employee concerned. The assumption was and is that the person whose personal exertion earns the income under the contract of employment derives that income and pays the tax.

We concluded that, in policy terms, the same general considerations apply to the taxation of the earnings of the self-employed from their personal exertion. It was recognised that in some cases capital assets may play some part in the derivation of income and in some circumstances it may be necessary to analyse the particular income-earnings in some detail. But there is no justification in principle for differentiating between salary and wage earners and professionals whose income is the

41 Hadlee v Commissioner of Inland Revenue [1991] 3 NZLR 517 (CA). See also Hadlee v Commissioner of Inland Revenue [1993] 2 NZLR 385 (PC). 
product of their personal exertion. In either case the person whose personal exertion earns the income derives the income.

\section{Re Simpson}

Re Simpson decided who was entitled to estate property in circumstances where there was uncertainty surrounding the deceased owner's parentage. ${ }^{42}$

Mrs Simpson had no children or siblings and her husband predeceased her. The question was whether she was the natural or adopted child of Mr and Mrs Wood, the persons she believed to have been her parents. If so, the property would be held on statutory trusts under the Administration Act 1969 for the qualifying family members. If not, it devolved to the Crown as bona vacantia but the Crown was empowered by s 77(1)(e) "to provide for dependants, whether kindred or not, of the intestate, and other persons for whom the intestate might reasonably have been expected to make provision.

Resolution of her parentage involved consideration of (1) the Births and Deaths Registration Act 1951 and its predecessors, including the receipt, consideration and recording of relevant data; (2) the adoption legislation at the relevant time and the earlier history of adoptions going back to the passage in New Zealand of the Adoption of Children Act 1881, the first adoption legislation in the British Empire, the principal purpose of which was to give the adoptive parents legal protection and security lacking under existing law and thereby to encourage the practice of adoption; ${ }^{43}$ (3) the admissibility of hearsay evidence of genealogy at common law in pedigree cases; and (4) assessment of considerable factual material.

The case required extended consideration of the legislation in its historical and social setting. As noted above, consideration of historical developments is basic to any legal argument. And so it is where the argument concerns the development of the common law, here the common law of New Zealand. In deciding that question for New Zealand law, and instead of simply focussing on the ancient stance of the common law of England and its development, we considered it helpful to canvass American, Canadian and Scottish material as well as English decisions and texts.

The Court concluded: ${ }^{44}$

There are no decisions of this Court in this area and we consider that it is in the public interest that at common law the Courts of New Zealand should not be required to insist on the independent proof of a strict blood relationship. Hearsay evidence is admitted in pedigree cases because there would otherwise be a failure of justice in those inevitable situations where it is not possible to prove by living witnesses

\footnotetext{
42 Re Simpson [1984] 1 NZLR 738 (CA).

43 See (1881) 39 NZPD 4.

$44 \operatorname{Re}$ Simpson, above n 42, at 725.
} 
the relationships of past generations. Gone are the days, if they ever existed in New Zealand, when it could be said that any relative has a greater interest in seeking information on the subject, a better opportunity for obtaining it and less reason for falsifying it. In some cases the degree of intimacy and confidence subsisting between the declarant and the person in question may be far closer than between some relatives in our mobile society. We favour adopting the Wigmore test [the most authoritative multi-volume American text on Evidence] as best calculated to advance the interests of justice in this country.

Applying that test to the facts of the case and reflecting the conclusions reached on the birth registration and adoption questions, we held that Mrs Simpson was not the natural child or adopted child of Mr and Mrs Wood. Her property devolved on the Crown.

That is not the end of the story. Dr G P Barton QC, who represented potential claimants in the High Court on the hypothesis, upheld by our ruling, that Mrs Simpson was neither the natural born nor the adopted child of Mr and Mrs Wood, has been able to confirm what then happened. The Crown was persuaded to apply s 77(1)(e) and pay the available funds to members of Mrs Simpson's family, as they were the persons for whom she might reasonably have been expected to make provision.

\section{Fleming v Securities Commission}

Fleming $v$ Securities Commission involved claims in negligence law in respect of failed investments against the Securities Commission and two newspapers. ${ }^{45}$ The plaintiffs invested money in Star Investments as a result of reading advertisements in The Taranaki Herald and The Daily News. It was assumed that these advertisements breached various provisions of the Securities Act 1978 and the 1983 Regulations. The plaintiffs sought damages from the Securities Commission and the newspapers.

We refused to impose a duty of care to individual investors on the Securities Commission. The Commission was charged with performing a wide range of both regulatory and law review and law reform functions while having a small staff and very limited budget. S 23(1) provided that no proceedings "shall lie against the Commission for anything it may do or fail to do in the course of the exercise ... of its functions, unless it is shown that it acted in bad faith or without reasonable care."

The statute clearly envisaged that the Commission exercised discretion in deciding how it went about exercising its functions. It was a supervisory agency with a limited role, not appropriate for the imposition of specific duties of care to all members of the investing public. The individual investors in this case could not be said to have placed such reliance on the Commission that they were in a relationship of proximity justifying such a duty.

45 Fleming v Securities Commission [1995] 2 NZLR 514 (CA). 
It was also argued that we should apply Anns v Merton London Borough Council ${ }^{46}$ and extend Hedley Byrne \& Co Ltd v Heller \& Partners Ltd $^{47}$ so as to impose liability on the newspapers. That would have had very serious consequences for the media and their readership.

In my judgment I observed: ${ }^{48}$

Advertisements are a feature of the mass media, print and electronic ... They facilitate commerce in the area served ... The volume of classified advertisements and the commercial need for them to appear in print within hours of their presentation for publication make it totally impracticable for a newspaper to investigate the factual accuracy of every advertisement, check compliance in all respects with legislation and the common law and verify authorisation for publication. ...

Essentially the newspaper is selling space for the advertisers to promote their goods and services. It is economically efficient for the responsibility for the accuracy, quality and legality of the advertising message to rest with the advertiser. The cost structure would have to change if the publisher had to accept or share that responsibility....

(F)inancial investments can never be risk free. And these advertisements were only a vehicle to allow potential investors to make contact with the finance company. The finance company had its statutory responsibility to register a prospectus and satisfy other requirements of the legislation. The investors had the opportunity to make inquiries about the investment and to assess the rewards and risks involved. The foreseeability of harm flowing from publication of non-complying advertisements is much diluted by the scope for immediate and fuller examination of the proposed investment before any commitment is made to it. ...

As a duty of care question, accuracy, reliability and lawfulness are all aspects of publication. The advertisement should be accurate, reliable and lawful. The advertiser may be liable civilly if it is not. To impose a duty of care on the media would open the door to liability in an indeterminate amount for an indeterminate time to an indeterminate class. It could inhibit the free flow of information and change the cost structure of the media to the detriment of commerce and the wider public.

In the result the economic consequences of imposing a duty were part of the standard Anns twostage analysis, along with foreseeability of harm, reasonableness of reliance and moral fault.

\section{Re Macfarlane}

Finally, and returning to the theme of the conference, Re Macfarlane is a striking example of the co-operative functioning of the three branches of government to resolve a seemingly intractable problem.

46 Anns v Merton London Borough Council [1978] AC 728.

47 Hedley Byrne \& Co Ltd v Heller \& Partners Ltd [1964] AC 465.

48 Fleming v Securities Commission, above n 45, at 531-533. 
The problem in Re Macfarlane and the steps taken to resolve it are explained in the John Donald Macfarlane Estate Administration Empowering Act 1918 and in the memoirs of OTJ Alpers, Canterbury schoolteacher, journalist, lawyer and Supreme Court Judge. ${ }^{49}$ His official role in the saga was as counsel for the Public Trustee who was representing Mr Macfarlane in the proceeding before the Supreme Court inquiring into a proposed Bill; and, after narrating the background and the steps he took as counsel, he went on to recount the unexpected aftermath. ${ }^{50}$

Mr Macfarlane had a 20,000 acre sheep station, "Hawkswood". He had a wife and six adult children. Three of the four sons were absent from New Zealand on Active Military Service. Unfortunately he suffered mental illness. In 1896 he had been found on inquisition to be a lunatic and had been in a mental institution near Dunedin for some 16 years. Land tax on that huge station was a great burden and was upwards of 50 per cent of the farming income. There was much to be said in the public interest for closer settlement of the property. But it could not be done in his lifetime. Or so it seemed. Until his lawyer had the idea of invoking the aid of Parliament. Before his mental trouble arose Mr Macfarlane had made a sensible will, which, if given effect, would provide his wife with a substantial annuity and enable division of the property amongst the family. The solicitors approached the government. A petition for a Private Estate Bill was filed.

The inquiry into the proposed Bill was before Herdman J. He was a very experienced lawyer and politician and had been Attorney-General in the Massey and National Governments from 1912 until his appointment to the Bench at Christchurch early in 1918. The psychiatric evidence was clear. There was no hope of recovery. The detailed provisions for the administration of the estate were settled. The Bill excluded from immediate distribution of the estate in terms of the will a sum to be set aside which would amply provide for Mr Macfarlane's maintenance and comfort, including a car and a chauffeur. It protected the life insurance companies by directing that his policies should not be payable until his actual death. The Judge certified under ss 281 and 282 of the Legislature Act 1908 his findings of fact, that the objects of the Bill were not attainable otherwise than by legislation and that the provisions of the Bill, if passed into law, would effect the proposed objects of the Bill.

Herdman J's decision was delivered on 18 October 1918. The first reading of the Bill was on 31 October. All Parliamentary processes, both in the Legislative Council and the House of Representative, including consideration by a special Select Committee, were completed within a month. The Bill was sent to the Committee for that body to examine it from all points of view and report back to the Legislative Council. The Committee did so, including calling the InspectorGeneral who gave evidence that he had personally examined Mr Macfarlane. He was convinced there was no reasonable hope that Mr Macfarlane would ever again recover any testamentary

49 OTJ Alpers Cheerful Yesterdays (John Murray, London, 1928) at 177-182.

50 Ibid, at 181-182 
capacity. The Committee unanimously concluded that it was in the public interest as well as in the interests of the family that so large a block of land should no longer continue in single ownership. ${ }^{51}$ The Bill was assented to and came into operation on 29 November. The statute empowered the Supreme Court to grant administration of the estate in terms of the will as if Mr Macfarlane had actually died on 29 November - the very day the Act had come into operation. All the children were deemed to have survived their father and to be living at that date and he was deemed to have been domiciled at "Hawkswood", enabling administration and distribution of his estate to be conducted through Christchurch rather than Dunedin.

These steps were all completed in the midst of the pressures on the Executive and the Legislature surrounding the cessation of hostilities - Armistice Day was 11 November 1918 - and under the shadow of the devastating influenza epidemic which was sweeping the country. In processing the Bill so promptly and making the will immediately effective the legislators recognised the complications which would have arisen if any beneficiary died in the meantime.

On 20 March 1919 the Supreme Court (Herdman J) granted Letters of Administration with the Will annexed to three sons of Mr Macfarlane. The family entered into their inheritance. The government received death duties well before it otherwise would. Everyone was happy.

Then, confounding the medical experts, Mr Macfarlane recovered his sanity. He returned home. When the saga was explained to him he took it in his stride and lived there until nature completed the process which the State had begun.

\section{CONCLUDING COMMENTS}

First, what makes a leading case is not immediately apparent or able to be expressed in a short definition. The case has to have had the most influence in settling an area of the law. More important are the "how" and "why" questions. How and why is the case now seen to be or to have been particularly significant. And those questions are also important in the research project for recovering New Zealand's "Lost" Cases, which is the central focus of this conference.

Exploring those questions necessarily involves historical analysis viewing the case in its historical context. Judges and lawyers (practising and academic) have the expertise to provide crucial perspectives. But the public policy impacts of court decisions are also the legitimate concerns of many others and the news media. And, as all lawyers know, consideration of historical developments is basic to any legal argument and its resolution, and so is awareness of economic and behavioural implications and impacts. Whether judges and lawyers are sufficiently open to other viewpoints is for others to assess.

51 The Hansard references are 183 NZPD 118, 182, 362, 387, 415 and 455 where the House, recognising the need for the greatest possible expedition, suspended the Standing Orders relating to Private Bills. 
Second, the paper discusses the empirical research involving retired judges, experienced lawyers and judges' clerks and the specialist essays by senior academic lawyers produced for the 50th anniversary conference of the Court of Appeal in 2008. The striking differences within and between the two lists and the particular reasons given by those participating in that research for selecting the cases and comparisons with cases discussed in the specialist essays bring out the real room for differing assessments of significance.

Part V A highlights insights from those contributing to the history essay and reflections on some cases they listed- and how they saw three of the most ranked cases. The interchange at the 20th anniversary symposium on the New Zealand Maori Council case shows how the straightforward legal questions there had become invested with a much wider significance, essentially because of the impact of the case on Maori-Government relations and ultimately on our political history. Invercargill City Council v Hamlin determined major issues of great practical significance concerning the liability of local authorities to home owners for the carelessness of their building inspectors. The ramifications of the case are still of huge practical significance in the continuing debate over liability for leaky buildings. Hosking $v$ Runting was a major privacy case concerning photographing families of celebrities out in the street. Five years on the guide posts are still far from settled.

Third, the second half of the paper is designed to bring out how and why in a range of appeal cases we drew on what we saw as matters of significance in reaching the decision.

The particular focus of King-Ansell was on language - determining the meaning of words in their context. It involved extended consideration of the processes for recording actual usages followed in the compilation of dictionaries and subsequent supplements.

In Van Gorkom it was on administrative functioning, settling limits to the exercise of governmental power and facilitating effective administration. Social changes over the last 30 years would, of course, bar what seemed a sensible administrative approach in the New Zealand of the late 1970s to the problem of a small bureaucracy dealing over the summer with an avalanche of claims for removal expenses of teachers transferring on promotion.

In DHL $v$ Richmond it was on the economic implications of decision-making. Commercial parties know that the protection the contract provides is factored into the price - you get what you pay for. If they enter into a low-priced courier contract $(\$ 22.50$ in the DHL case for conveying a package to Italy) that excludes liability on the part of the courier, then they are electing to bear any resulting losses.

In Hadlee $v$ Commissioner of Inland Revenue the particular focus was on statutory interpretation, reflecting the historical development of the statutory subject matter and the policies underlying related categories. We concluded that there was no justification in principle for differentiating between salary and wage earners and professionals whose income is the product of 
their personal exertion. In either case the person whose personal exertion earns the income derives the income and pays the tax.

In Re Simpson it was on the development of the common law of New Zealand. Instead of simply focussing on the ancient stance of the common law of England and its development there, we considered it helpful to canvass American, Canadian and Scottish material and adopted the Wigmore test as best calculated to advance the interests of justice in New Zealand. And, while the reported judgment was silent as to the ultimate destination of the property, checking confirmed that the Crown was persuaded to apply a statutory provision and pay the available funds to members of Mrs Simpson's family.

Fleming was concerned with the duty of care in negligence. The Court rejected claims against the Securities Commission and two newspapers in respect of failed investments in a finance company made as a result of reading its newspaper advertisements. The Commission was a supervisory agency with a limited role and clear discretion in deciding how it went about exercising its functions. Rejecting the claim against the newspapers, we concluded that they were essentially selling space for the advertisers to promote their goods and services and the advertisements were only a vehicle to allow potential investors to make contact with the finance company.

Finally, Re Macfarlane is an example, reflected elsewhere in our law, of the co-operative functioning of the three branches of government. While not as exciting as relishing the clash of possible standoffs between the Courts and the Legislature, it does represent day to day reality. 